ビン酸 $20 \mathrm{mg}$ を添加したのち，MXB 溶液を加えるこ とにより 10 倍量が共存しても妨害しないことがわかっ た。

\section{7 錯体の組成}

連続変化法により錯体の組成比を求めた結果を Fig. 3 に示す. ビスマスと MXB の比はほぼ 1:1 と推定さ れる。

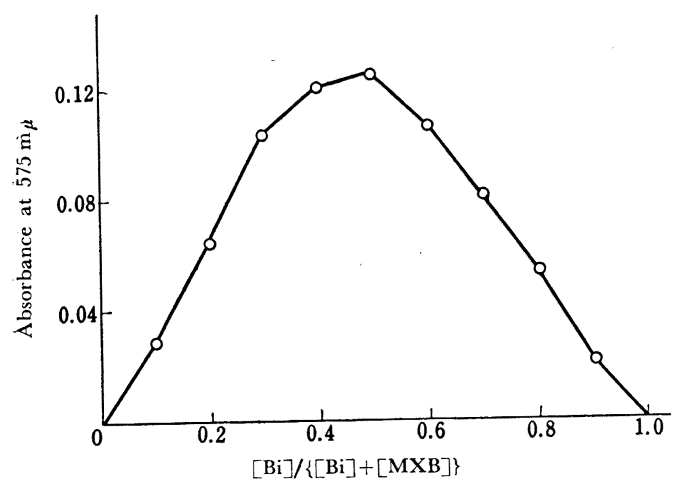

Fig. 3 Continuous variation method $[\mathrm{Bi}]+[\mathrm{MXB}]=3.83 \times 10^{-5} \mathrm{M} ; \mathrm{pH}: 1.3$

\section{5 応用分析例}

本法の実用性を確かめるため, 鉛に一定量のビスマス を添加し回収実験を行なった。 JIS 1 級の鉛約 $1 \mathrm{~g}$ を精 ひょうし，ビスマス $1 \mathrm{mg}$ 相当量のビスマス標準溶液と ともに，硝酸 $(1+4) 10 \mathrm{ml}$ で加熱分解し 蒸発乾固す る. 残さを $1 N$ 硝酸 $20 \mathrm{~m} l$ に溶かし, さらに水でうす め $100 \mathrm{ml}$ としたのち乾燥沪紙 (No. 5C) で沪過する. 沪液 $10 \mathrm{ml}$ をとり，3 の操作 (MXB 溶液添加の前 に L-アスコルビン酸 $20 \mathrm{mg}$ を加える）を適用したの ち，ビスマス無添加の鉛試料における，から試験値を差 乙引き，検量線からビスマスの回収率を求めた。5 回の 実験結果からの平均回収率は 95.4\% であり, 標準偏差 は $0.37 \%$ であった。

\section{交献}

1) Dotite News Letter, 16, No. 2, 17 (1968).

2) 椿 勇, 中西 務：日本分析化学会第 18 年会 講演要旨集, p. B 152 (1969).

3) 西岡利国：日本化学会, 日本分析化学会, 高分子 学会中国四国支部合同松山大会講演要旨集, p. 37 (1969).

4) 出口正一, 坂井紘治 : 本誌, 19, 241 (1970).
Colorimetric determination of bismuth with Methylxylenol Blue. Masakazu Deguchi*, Itsuo OKumurA** and Kouji SAKAI*** (*Department of Applied Chemistry, Faculty of Engineering, Hiroshima University, Senda-machi, Hiroshima-shi; **Hiroshima City Art and Industry Institute, Higashihonura, Hiroshima-shi; ***Identification Section, Hiroshima Prefectural Police Headquarters, Moto-machi, Hiroshima-shi)

Bismuth formed a red-violet complex with Methylxylenol Blue (MXB) in an aqueous solution, and it was applied for a colorimetric determination of bismuth. The complex had an absorption maximum at $575 \mathrm{~m} \mu$, and the absorbance was constant over the $\mathrm{pH}$ range from 1.2 to 1.3. Beer's law was obeyed over the range from 20 to $180 \mu \mathrm{g}$ of kismuth in $25 \mathrm{ml}$ solution. The molar extinction coefficient was about 8900 .

The established analytical procedure was as follows. The samp'e solution containing 20 to $180 \mu \mathrm{g}$ bismuth was mixed with suitable amounts of $0.2 \mathrm{~N} \quad \mathrm{HNO}_{3}$ and $1.0 \mathrm{ml}$ of $0.1 \% \mathrm{MXB}$, and made up to $25 \mathrm{ml}$ with water (the final $\mathrm{pH} 1.2 \sim 1.3$ ). After 5 minutes, the absorbance was measured at $570 \mathrm{~m} \mu$ against the reagent blank.

Iron(III), thorium(IV) and molybdenum(VI) interfered, but the permissible amount of iron(III) was increased by addition of $\mathrm{L}$-ascorbic acid.

This method was simple and the results of recovery tests on synthetic samples (lead+bismuth) were satisfactory.

(Received Dec. 9, 1969)

\section{pH 滴定法による強リン酸の組成分析}

\author{
石井大道, 後藤正志, 林田一義* \\ (1969 年 12 月 24 日受理)
}

1 緒馬

強りン酸は常温では, 粘性の水あめ状で化学作用はほ とえどないが，加熱すると粘性を失い諸種の物質に対し て著しい解砕作用を示し, 分析化学において難溶性試料 の溶解剤として広く使用されている，その効力が強リン 酸の組成によって若干異なるようであるので，ホーラロ グラフィーの研究1) 3) と関連して強りン酸の組成を検定 することを目的として，従来のイオン交換また法べーパ 一クロマトグラフィーによる分離後加水分解に上ってオ

* 名古屋大学工学部工業分析化学第一講座 : 名古屋市 千種区不老町 
ルトリン酸としたのち比色法で定量するかわりに， $\mathrm{pH}$ 滴定法による簡易組成分析法について検討した．分析に 多く用いられるのは五酸化リン $77 \mathrm{wt} \%$ 付近の強りン 酸であり，これはほとえどオルト，ピロ，トリポリおよ びテトラポリリン酸のみから成っている之考えられてい る.

そこでこれら 4 種のリン酸の混合物の分析を対象とし て基礎実験を行なった。

\section{2 測定原理}

オルト，ピロおよびトリポリリン酸の電離定数4) は Table I に示寸とおりであり，鎖状縮合リン酸は 1 分子 中にリン原子 1 個あたり 1 個の強酸性水素と両末端にそ れぞれ 1 個の弱酸性水素を有している5)6). したがって オルト，ピロ，トリポリおよびテトラポリリン酸の混合 水溶液をアルカリ（水酸化ナトリウム）で滴定すれば, 第 1 変曲点までのアルカリ消費量は強酸性水素イオン量 すなわち全りン量に相当し，第 1 と第 2 変曲点との間の アルカリ消費量はオルトリン酸の第三水素を除く弱酸性 水素イオン量に相当することになる7). 次に第 2 変曲点 を少し過ぎたところで試料溶液に塩化カルシウム溶液を 添加すれば，次式のようにリン酸カルシウムが沈殿しオ ルトリン酸の第三水素汇相当する塩酸が遊離する.

$$
\begin{aligned}
& 2 \mathrm{Na}_{2} \mathrm{HPO}_{4}+3 \mathrm{CaCl}_{2} \\
& \quad \longrightarrow \mathrm{Ca}_{3}\left(\mathrm{PO}_{4}\right)_{2}+4 \mathrm{NaCl}+2 \mathrm{HCl}
\end{aligned}
$$

この塩酸を引き続きアルカリで滴定することによりオ ルトリン酸が 定量できる．以上の典型的な滴定曲線を Fig. 1 亿示す. 一方，pH 3.8〜3.9 亿調節した別の同 じ試料溶液に酩酸亜鉛溶液を加えると 4 種のリン酸中ピ ロリン酸亜鉛だけが沈殿する899．この沈殿を分離して 容量法によりピロリン酸を定量する.

Table I Ionization constants of phosphoric acids

\begin{tabular}{lccccc}
\hline \hline Phosphoric acid & $\mathrm{p} K_{1}$ & $\mathrm{p} K_{2}$ & $\mathrm{p} K_{3}$ & $\mathrm{p} K_{4}$ & $\mathrm{p} K_{5}$ \\
\hline Ortho $\left(\mathrm{H}_{3} \mathrm{PO}_{4}\right)$ & 2.15 & 7.20 & 12.44 & - & - \\
Pyro $\left(\mathrm{H}_{4} \mathrm{P}_{2} \mathrm{O}_{7}\right)$ & small & 2.64 & 6.76 & 9.42 & - \\
Tripoly $\left(\mathrm{H}_{5} \mathrm{P}_{3} \mathrm{O}_{10}\right)$ & small & small & 2.30 & 6.50 & 9.24 \\
\hline
\end{tabular}

今，混合溶液中に含安机るオルト，ピロ，トリポリお よびテトラホリリン酸のモル数をそれぞれ $x_{1}, x_{2}, x_{3}, x_{4}$ とし，第 1 変曲点まで，第 1 から第 2 変曲点まで，第 2 斿ら第 3 変曲点までに要したアルカリの消費量（モル 数）をとれぞれ $\mathrm{A} ， \mathrm{~B} ， \mathrm{C}$ お上び容量法により求めたピ ロリン酸亜鉛のモル数を Dとすれば次式に示すような関

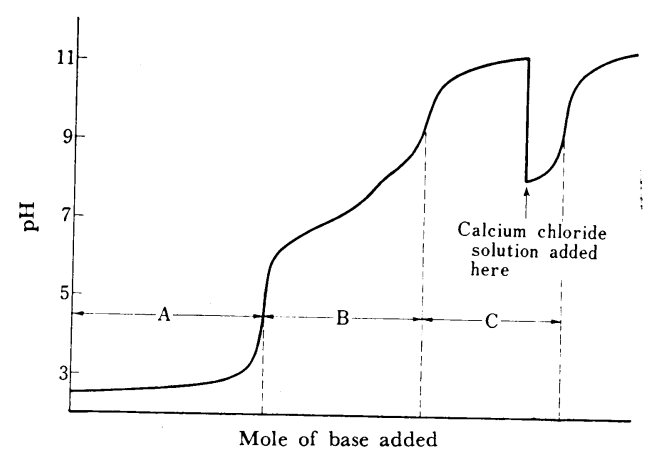

Fig. 1 Typical titration curve

係が成立する。

$$
\begin{aligned}
& x_{1}=\mathrm{G} \\
& x_{2}=\mathrm{D} \\
& x_{1}+2 x_{2}+3 x_{3}+4 x_{4}=\mathrm{A} \\
& x_{1}+2 x_{2}+2 x_{3}+2 x_{4}=\mathrm{B}
\end{aligned}
$$

これらの連立方程式を解くことにより各リン酸の存在 量を知ることができる.

\section{3 装置および試薬}

$\mathrm{pH}$ 測定には平沼製 RAT-1 型滴加制御式滴定記録装 置を使用し，電極にはガラス電極および飽和カロメル電 極を用いた。試薬はすべて市販特級品を用いた。オルト リン酸としてはリン酸二水素カリウム，ピロリン酸とし てはピロリン酸ナトリウム 10 水塩を $\mathrm{H}$ 型陽イオン交換 樹脂 (Amberlite IR-120H 型) 柱を通してえれぞれの 酸に変えて用いて検討した。滴定には除炭酸した $0.1 N$ 水酸化ナトリウム標準溶液を用いた。

\section{4 実験および結果}

強りン酸の約 $1 \mathrm{~g}$ をひょう量びえを用いて精ひょう し，蒸留水で希釈して $100 \mathrm{ml}$ の溶液とする。この試料 溶液 $5 \mathrm{ml}$ を $100 \mathrm{ml}$ 容ビーカー中に採取し, 蒸留水で 約 $50 \mathrm{ml}$ に希釈してから電極を設定し， pH 自動滴定 記録装置を用いて $0.1 N$ 水酸化ナトリウム標準溶液で滴 定する. 第 1 回目の滴定では，第 2 変曲点省し過ぎた ところで塩化カルシウム溶液を添加し大略のオルトリン 酸存在量を知り，第 2 回目の滴定に打いてリン酸水素二 ナトリウムをできるだけリン酸ナトリウムに中和してお いてから，塩化カルシウム溶液を必要理論量の約 1.5 倍 量を加えて完全な滴定曲線を記録する。この滴定曲線の 第 2 变曲点法次節に従って補正与る. 一方, 別に $5 \mathrm{ml}$ の試料溶液を採取して $\mathrm{pH}$ を3.8〜3.9 に調節し，酢 酸亚鉛溶液を加えて室温で約 15 分間放置したの方，生 
成した沈殿を No. 5C 万紙を用いてろ過する9). 次に， この沈殿をH型陽イオン交換樹脂 (Amberlite IR-120H 型）の少量とともにかき混ぜて蒸留水に溶解し，さらに イオン交換樹脂柱の中を通して完全に酸に変えたのち, $0.1 N$ 水酸化ナトリウム標準溶液で滴定してピロリン酸 を定量する.両方の測定結果を（1）（4）の連立方程式 に代入して各リン酸の存在量を求める.

85\% オルトリン酸を原料として高木の加熱脱水法 ${ }^{10)}$ により調製した 4 種類の強りン酸について, 上記の方法 で組成分析を試みた結果を Table II に示す. 本実験結 果は従来のイオン交換およびペーパークロマトグラフィ 一によって得られた交献值1112) とほぼ一致した。

Table II Composition of strong phosphoric acid

\begin{tabular}{cccccc}
\hline \hline $\begin{array}{c}\text { Sample } \\
\text { no. }\end{array}$ & $\begin{array}{c}\text { Total } \\
\mathrm{P}_{2} \mathrm{O}_{5} \\
\text { (wt\%) }\end{array}$ & $\begin{array}{c}\text { Ortho } \\
\begin{array}{c}\mathrm{H}_{3} \mathrm{PO}_{4} \\
(\text { wt\%) }\end{array}\end{array}$ & $\begin{array}{c}\text { Pyro } \\
\mathrm{H}_{4} \mathrm{P}_{2} \mathrm{O}_{7} \\
\text { (wt\%) }\end{array}$ & $\begin{array}{c}\text { Tripoly } \\
\mathrm{H}_{5} \mathrm{P}_{3} \mathrm{O}_{10} \\
\text { (wt\%) }\end{array}$ & $\begin{array}{c}\text { Tetrapoly } \\
\mathrm{H}_{6} \mathrm{P}_{4} \mathrm{O}_{13} \\
\text { (wt\%) }\end{array}$ \\
\hline 1 & 74.6 & 73.1 & 26.9 & - & - \\
2 & 76.5 & 47.4 & 44.5 & 5.9 & 2.2 \\
3 & 77.9 & 35.4 & 48.3 & 12.9 & 3.4 \\
4 & 79.4 & 14.4 & 33.0 & 29.7 & 22.9 \\
\hline
\end{tabular}

\section{5 考察}

本分析法において問題となるオルトリン酸定量のため の基礎的条件を検討した結果を次代記す.リン酸水素二 ナトリウム海化カルシウムと反応して, リン酸カルシ ウムの结ふに一部りン酸水素カルシウムを生成しこれが 沈殿中に台去れるので, 塩化カルシウム溶液の添加位置 はおそい涊ど定量誤差が小さくなる。なお，塩化カルシ ウム溶液脑 $\mathrm{pH}$ を7 亿調節したものを用いる必要があ る.

滴定試料溶液中のオルトリン酸濃度はあまり濃すぎる と生成した沈殿のため電極の応答性がわるくなるので $M / 100 \sim M / 200$ ぐらいになるように希釈するのが適当 である・交たりン酸カルシウムの沈殿生成反応は室温で もすみや方汇進行することを確認した. Table I の電離 定数から明らかなように，ピロリン酸が共存すると滴定 曲線の第 2 変曲点ではすでに数\%のリン酸水素二ナトリ ウム泣リン酸ナトリウムにまで中和されていることにな る.し心し，ここで問題としている五酸化りン $77 \mathrm{wt} \%$ 付近 $(74 \sim 80 \mathrm{wt} \%)$ の強リン酸中に含有されていると 考えら礼る各割合でオルトリン酸に対してピロリン酸を 共存させて検討した結果, これくらいの範囲の割合で ピロリン酸が共存するときは滴定曲線の第 2 変曲点から $\mathrm{pH}$ が 0.25 だけ低いところを当量点（真の第 2 変曲点） とすればほぼこれを補正できることを見いだした。

\section{6 結 語}

本分析法によって，加水分解の必要なく滴定曲線の第 1 変曲点までに要したアルカリ量から全リン量を精度よ く簡単に定量でき，またピロリン酸を除く各種リン酸を 分離することなく短時間で五酸化りン $77 \mathrm{wt} \%$ 付近の 強りン酸の組成它決定することが可能になった。

\section{$\left(\begin{array}{l}1966 \text { 年 } 11 \text { 月 } 2 \text { 日, 日本化学 } \\ \text { 会東海支部大会において発表 }\end{array}\right)$}

\section{交献}

1) 品川睦明, 柳 忠, 後藤正志 : 日化, 88,60 (1967).

2) 後藤正志, 石井大道 : 同上, 89, 864 (1968).

3) 後藤正志, 石井大道 : 同上, 90, 376 (1969).

4) 大橋 茂編：“無機化学全書”, IV-6 (リン), p. 190 (1965), (丸善).

5) 大橋茂:工化, 66, 538 (1963).

6) J. R. Van Wazer, E. J. Griffith, J. F. McCullough : Anal. Chem., 26, 1755 (1954).

7) 酒井昭四郎, 大藏律子：本誌，15，507 (1966).

8) E. V. Britzke, S. S. Dragnov : J. Chem. Ind., 4, 49 (1927).

9）加藤多喜雄, 萩原善次, 簙沢亮二郎 : 本誌, 4, 486 (1955).

10）高木友雄：同上, 4, 625 (1955).

11) S. Ohashi, H. Sugatani : Bull. Chem. Soc. Japan, 30, 864 (1957).

12) A. L. Huhti, P. A. Gartaganis : Can. J. Chem., 34, 785 (1956).

$$
\text { is }
$$

Composition analysis of strong phosphoric acid by pH titration method. Daido IsHII, Masashi Goto and Kazuyoshi Hayashida (Institute of Techno-Analytical Chemistry, Faculty of Engineering, Nagoya University, Chikusa-ku, Nagoya-shi)

A simple method for the composition analysis of strong phosphoric acid involving ortho-, pyro-, tripoly- and tetrapoly-phosphoric acid has been given. The diluted sample solution was titrated with an alkali using an automatic titrometer with recorder. Calcium chloride solution was added at a position just beyond the second inflection point of the titration curve and the titration was continued to the third inflection point. The moles of base required from the beginning to the first, from the first to the second and from the second to the third inflection point of titration curve are equivalent, respectively, to the content of strongly acidic hydrogen ion or total phosphorus atom, weakly acidic hydrogen ion except the third hydrogen of orthophosphoric acid and the third hydrogen ion of orthophosphoric acid. On the other hand an aliquot of the sample solution was brought to $\mathrm{pH} 3.8 \sim 3.9$, and pyrophosphoric acid was determined after precipitation as zinc salt. The strong phosphoric acid prepared by heating $85 \%$ orthophosphoric acid were analyzed by this method and reasonable results were obtained.

(Received Dec. 24, 1969) 